\title{
Effects of Property Tax on Sustainable Housing Delivery in Lagos State, Nigeria
}

\author{
ONI Ayotunde Olawande (Corresponding author) \\ Department of Estate Management, School of Environmental Studies \\ College of Science \& Technology, Covenant University \\ Ota, Ogun State, Nigeria \\ Tel: 234-802-3122-014Ｅ-mail: wandeoni@yahoo.com
}

\author{
AJAYI Cyril Ayodele \\ Department of Estate Management \\ Obafemi Awolowo University \\ Ile-Ife, Osun State, Nigeria \\ Tel: 234-803-725-8925Ｅ-mail: ydlajayi@yahoo.com
}

\begin{abstract}
Increasing demand for urban and rural infrastructures and dwindling revenue allocations in Nigeria have informed the Lagos State Government to promulgate Land Use Charge Law (2001) as a way of increasing internally-generated revenues through property tax. The Law stipulates a formula for assessing the Charge payable on properties in Lagos State, amongst other provisions. The aim of this paper is to determine the shortand long- term effects of the law on housing delivery which is one of the thematic areas of Vision 20:2020 for Nigeria. A process of inferences was adopted to evaluate the law in addition to questionnaires administered on Estate Surveyors and Valuers within Lagos metropolis. The study found that the formula is inappropriate and that high tax and penalties may discourage investment in new housing and maintenance of existing stock. It therefore recommended a review of the Law and in addition suggested an appropriate basis of fair and equitable tax such that the goal of Vision 20:2020 can be realizable.
\end{abstract}

Keywords: housing, land use, property tax, revenue allocation, Lagos State, Nigeria

\section{Introduction}

Conceptually, Nigeria's economic potential is well recognized as the biggest economy in the West Africa sub-region with considerable resource endowment being a pointer to strong growth. However, very little of such potential seems to have been realized. This is associated with unsustainable planning and visioning, economic stagnation, declining welfare and social instability in the past thirty years. The main objective of Vision 20:2020 is therefore to make Nigeria one of the twenty largest economies in the world with ability to consolidate its leadership role in Africa and establish itself as a significant player in the global economic and political arena by the year 2020.

There are twenty-nine thematic areas assigned to the National Technical Working Group of Vision 20:2020, one of which is Housing. The responsibility of Governments at all levels in providing infrastructure and housing is enormous. Such infrastructure may be rural and urban, referring to roads, sewers, or utility lines, and may include hospitals, schools, emergency services like fire fighters and police, sidewalks, or ponds to hold storm-water. The basic facilities make a town or city to function effectively and are also required for national development (Collins, 2003; Tesfay, 2008).

Funding of infrastructure, especially in urban areas in time of dwindling revenue allocations from the Federal Government, has posed great challenge to State and Local Council Governments. This has led_the Lagos State Government to source for a new means of generating additional revenue internally through property tax. The Land Use Charge Law 2001 was therefore a creation of the Lagos State Government to give legal backing to revenue generation through property taxation in order to provide sustainable housing delivery.

A number of questions arise: What will be the short- and long-run effects of the provisions of the Land Use Charge Law on housing delivery in Lagos State in view of Vision 20:2020? Is the basis for calculating the charge reasonable? What is the position of Estate Surveyors and Valuers regarding the provisions of the Law? What is sustainability and sustainable housing delivery? What impact(s) will the Law have on sustainable housing delivery in the study area? The aim of this paper is to examine the Land Use Charge Law (2001) and determine 
its effects on sustainable housing delivery in view of Nigeria's Vision 2020. In doing so, succeeding sections cover the challenge, basic method of determining fair and equitable property tax, highlight the provisions of the Law, and analyze the opinions of practicing Estate Surveyors and Valuers followed by appropriate recommendations.

\section{The Challenge}

The rate of urbanization in Nigeria has tremendously increased in the last two decades. Census in the early fifties showed that about $10.6 \%$ of the total population lived in the cities. This rose dramatically to $19.1 \%$ in 1963 , and $24.5 \%$ in 1985 . Today, the national population is estimated to be 150 million with the urban population constituting of about 30\%. The Lagos metropolis has grown in terms of population. According to the 1991 national census, Lagos State had a population of 5725116 out of a national total of 88992 220. Although the 2006 National Census credited the metropolitan area with a population figure of 7937932 the more reliable population figure given by the Lagos State Government is 17553924 based on enumeration that was conducted for social planning. This population figure is projected to reach 24.5 million by the year 2015 , thereby making it to be among the ten most populous cities in the world (Lagos State Official website). Details of the population by Local Government Council Areas are shown in Table 1.

In terms of revenues, the Federation Account serves as a pool account where all federally collected revenues are paid as required by the 1999 Constitution and shared among the Federal, State and Local Governments. The revenue allocations to Lagos State between January, 2004 and December, 2009 are shown in Table 2. The increase in revenue into the Federation Account between 2004 and 2007 (15.6\%; 8.8\% and 60\% respectively) was buoyed by high crude oil prices, which peaked at $\$ 147$ per barrel before the oil price recession which was occasioned by global economic crisis and incidences of militancy and kidnapping of oil workers in the Niger Delta. Fig. 1 illustrates the growth pattern of revenue allocations to Lagos State from 2004 to 2009. However, Federal Allocations and internally-generated revenues indicate wide variation ( $28 \%$ against $72 \% ; 14 \%$ against $86 \%$ and $10 \%$ against $90 \%$ respectively), as shown in Table 3 and illustrated by Fig. 2.

Table 3 indicates that the internally-generated revenues have been increasing while federal allocations have decreased steadily from 2007; and Fig. 2 shows that there is $83.8 \%$ probability that the Federal Allocation in the coming years may decrease further. This might be attributable to uncertainty in the political terrain at the Federal level and dwindling oil revenue. Also, all things being equal, there is $99.3 \%$ probability that the internally-generated revenue in Lagos State will continue to increase due to government's aggressive drive to generate additional income through tax, fines, and levies. The aggressive revenue drive has partly dictated government's action to fuse the various forms of multiple taxes, namely, Land Rates Law (Cap. 112), Neighbourhood Improvement Charge Law (Cap 136), and Tenement Rate Law (Cap. 186) into the Land Use Charge Law (2001).

\section{Theoretical Framework}

This is examined under the principles and basis of taxation, principles of valuation, sustainability and sustainable housing delivery.

\subsection{Principles and Basis of Taxation}

Tax is the amount levied on an individual, group or corporate entity and payable to government to meet expenditure on infrastructure and keep the organs of governance running smoothly. Taxation has become an indispensable part of modern economic systems worldwide, with wide variety of different tax models. Such tax is expected to be fair and equitable; set in simple and clearly understandable language; considering the ability of each person to pay based on income; politically acceptable to the payers to avoid incurring their hostility; and must be consistent with goals of promoting stable economy (Silvani and Paulo dos Santos, 1996; Tait, 1988; McLure, 2000; Ehtisham and Stern, 1991; Serra and Afonso, 1999; Bird and Gendron, 2000; Keen and Smith, 2000; Emeni, 2000; Olusegun, 2003; Ogbuefi, 2004; Sharma, 2005; Thacker, 2009).

In determining the appropriate method of tax assessment, Harvey (2000) opined that it is usual for local property taxes to be levied ad valorem with net annual value (NAV), capital value or site-value being the basis of assessment. An ad valorem is Latin for "according to value", and ad valorem tax is based on the value of real estate or personal property. It is typically imposed at the time of a transaction (a sales tax or value-added tax) and may be imposed on an annual basis (real or personal property tax), or in connection with another significant event (inheritance tax, surrendering citizenship, or tariffs), or the amount that an owner of real estate or other property pays on the value of the property being taxed. Most ad valorem taxes are placed on the net price and imposed on the receipts from the sale of a commodity including the amount paid out as taxes (Taubman, 1965); 
while the basis for ad valorem taxation is the fair market value of the property levied on the assessed value of the property which is determined by the tax rate (mill rate) multiplied by the assessed value (the Oklahoma Ad Valorem Laws, 2001; and Denson, 2009).

When net annual value is the basis of assessment, it is likely to be determined as follows: Gross annual value which is the yearly rent that a property might reasonably be expected to let on a determined rate and with deductions made for maintenance and insurance and other outgoings to give the net annual value. Compared with site-value basis, NAV has certain advantages because the base includes buildings as well as land; the yield is higher especially for properties whose building cost is a high proportion of the total cost. It is easier to assess, since in a free market, rentals can be determined by comparison of prevailing rent on similar properties within same neighbourhood. In using the capital value basis, tax will be the value of premises if sold in the open market in a transaction involving a willing and able buyer and seller, and provided that capital value equals net annual value capitalized at the relevant rate of interest (Newell, 1977). Capital value, in this respect, is the amount of money which may be obtained for an interest at a particular time from individuals who are able and willing to purchase it. It is the price arrived at under an open market normal financing, non-cohesive, non-monopolistic condition, and by private treaty at a particular date assuming willing seller, reasonable period within which to negotiate the sale, taking into account the nature of the property and the state of the market, with the property freely exposed to the market (Richmond, 1975; Johnson, Davis and Shapiro, 2003; Millington, 1982; N I E S V, 1985; Ajayi, 1998; and Kalu, 2001).

Lean and Goodall (1977) stated that the basic economic effect of tax is that the open market price will increase in the long run if there is higher demand for a good or service. Similarly, the higher the outgoings in form of tax liability, the higher will be the rent that landlord will demand for a given property on the long run. In this regard, where initial capital costs cannot be set off against tax liability whereas maintenance expenditure can be, this will increase additional expenditure on maintenance rather than initial construction. In respect of supply of properties, Harvey (2000) opined that in the short-run the stock of rented houses is fixed while new rates will be borne by owners and the net rent will fall. In the long run, supply of houses will be more elastic since, assuming no planning consent is required, owners will adapt them to other uses or simply not replace them as they wear out, switching to lower-taxed and profitable forms of investment. The tax burden is then passed on to the tenants; however, its extent depends upon the relative elasticity of supply and demand.

According to Harriss (2009), every increase in property-tax rates on structures (not land) reduces the desirability of putting capital funds into new buildings, creates an incentive against upgrading quality by new construction, and discourages maintenance. It also leads to the construction of rooms, apartments, and buildings somewhat smaller than would be the case in the absence of tax.

\subsection{Principles and Methods of Property Valuation}

Ifediora (2005) identified five methods that an Estate Valuer, in his specialist functions, uses to determine the capital and rental values of interests in land or land and building. The methods are cost (contractor's test) approach, sales comparison (comparative or comparable) approach, income (investment) approach, account (profits), residual (development), and depreciated replacement cost approach. According to the Uniform Standard of Professional Appraisal Practice (2008-2009), the fundamental premise of the cost approach is that a potential user of real estate will not pay more for a property than it would cost to build an equivalent and that the cost of construction minus depreciation, plus land is a limit of market value.

The cost approach is also called the summation approach, or contractor's method. The theory is that the value of a property can be estimated by summing the land value and the depreciated value of any improvements. The value of the improvements is often referred to as reproduction cost new less depreciation or replacement cost new less depreciation. Reproduction refers to a construction of an exact replica. Replacement cost refers to the cost of building a house or other improvement which has the same utility, but using modern design, workmanship and materials. In practice, appraisers use replacement cost and then deduct a factor for any functional disutility associated with the age of the subject property. The method is used in the valuation of certain types of properties which seldom change hands in the property market and for which there are few comparables. Such properties include Police Stations, Hospitals, Local Government Council and State Secretariat, Schools, Military cantonment and barracks, Town Halls, and Libraries. The method is based on the assumption that: the value of land and building is equal to the value of the site plus cost of erecting the building. The comparison method assumes that a prudent individual will pay no more for a property than it would cost to purchase a comparable substitute property. It recognizes that a typical buyer will compare asking prices and seek to purchase the property that meets his or her wants and needs for the lowest cost. The method is used where 
there is good evidence of recent sales of properties similar to the subject being valued. The method is a process of comparing market data transactions in property and consists of the analysis of price paid for comparable properties by purchasers.

The income capitalization approach is based on the premise that capital value of an interest in landed property is directly related to the income derivable from such interest. Such income can be readily established from actual rental income paid or from comparison of rents on similar properties. The value of such landed property is expressed as the product of the net income and the inverse of the market yield. The yield reflects both the attractiveness of the investment to purchasers in the market and such principal considerations as capital security, income security, and growth prospects, ease of sale, ease of management, and returns on other investments. The approach is used to value commercial and investment properties. In a commercial income-producing property this approach capitalizes an income stream into a value indication using revenue multipliers or capitalization rates applied to the first-year Net Operating Income. The Net Operating Income (NOI) is gross potential income (GPI), vacancy and collection loss (equals Effective Gross Income) less Outgoings (but excluding debt service, income taxes, and/or depreciation charges applied by accountants). Alternatively, multiple years of net operating income can be valued by a discounted cash flow analysis (DCF) model. The DCF model is widely used to value larger and more expensive income-producing properties, such as large office towers. This technique applies market-supported yields (or discount rates) to future cash flows (such as annual income figures and typically a lump reversion from the eventual sale of the property) to arrive at a present value indication. The method is most applicable to valuation of property purchased for investment to produce the rental income. It is also suitable for valuation of leasehold interest where direct comparables of similar property let on similar terms are most unlikely to be available but where comparable evidence might well be available for rental values and capitalization rates. The analysis of previous transactions is a prerequisite of investment method and a comparative principle is at the heart of the process, and it follows a process consisting of: estimating the gross income from the property; quantifying and deducting outgoings from the gross income; deriving the Net Income; determine the capitalization rate; and obtaining the Capital Value by multiplying the net income with the capitalization rate. The outgoings include expenses on repairs, insurance, management, services, rates, and rents payable under the lease. Whether responsibility for outgoings lies with the landlord, tenant or sub-tenant will be determined by agreement. It is important to examine the lease agreement to check liabilities.

The Profits Method is applicable to properties such as hotels, motels, public house, cinemas, theatres, sport grounds, and amusement parks. A three-year average of operating income derived from the profit and loss or income statement is capitalized using appropriate yield. The value got from the use of the method is wholly or partly dependent on the capacity of such subject property to earn income. It is based on the assumption that such values are related to the profits made or to be made in the course of occupation and use of the property. With this method, the Estate Valuer attempts to determine the rental value of the subject property and not the capital value. The basic equation of the Profits Method is: Average Annual Gross Earnings of the Property less the Working Expenses (excluding property rental) and amount for the occupier's remuneration, including interest on the capital tied up in the business. The balance represents the amount available for annual rent which is capitalized by appropriate Years' Purchase to arrive at the capital value of the subject property.

The Residual Method is used for properties ripe for development or redevelopment or for bare land only. It is used when a property has the potential for development and redevelopment, and where higher values can be realized by the expenditure of capital resources. Also, it is applicable where planning permission can be obtained for the development or development of the site. The costs of construction and other site works, architects' and quantity surveyors' fees, legal fees, advertising costs, estate agency fees, interest rates on borrowed capital, and developers profit are subtracted from the Gross Development Value. The balance or residue is the value for the bare site. The basic formula for the residual method of valuation is: Gross Development Value or Gross Realization Less Total Costs of Development (including the Developers' Profit) equals Value of the bare site in its present condition.

\subsection{Sustainability and Sustainable Development}

The core idea of sustainability was defined by The World Commission on Environment and Development (i.e., The Brundtland Commission of 1987) as "development which meets the needs of the present without compromising the ability of future generations to meet their own needs". However, a number of concepts have emerged since 1987. Sustainable development has been defined in terms of value change, social reorganization, vision expression, moral development, or transformational process toward a desired future or better world (Clark, 1989; Gore, 1992; Lee, 1993; Rolston, 1994; Jones, Reid, and Gilbert, 2003). Sustainability has also been regarded as a relationship between dynamic human economic systems and ecological systems in which human 
life continues indefinitely, in such a way that human activities do not destroy the diversity, complexity, and function of the ecological life support system (Costanza, Daly, and Bartholomew, 1991). According to Stern, Young, and Druckman (1992), sustainability means that both environmental and human systems must be the catalyst for population change, economic growth, technological change, political and economic institutions. This concept goes beyond the efficiency of human beings in relation to the natural environment by taking into consideration the social sufficiency. It is based on the premise that no nation can reach its economic goals without also achieving social and environmental goals.

\section{Material and Method}

According to the NIESV (2009), there are two hundred and seventy firms of Estate Surveyors and Valuers in Lagos metropolis. One respondent was consequently selected in each firm to make up the study population, and appropriate sample size of the population was selected based on Bartlett, Kotrlik, and Higgins (2001) model. The model recommends the appropriate sample size given a population size and alpha level of $95 \%$. In this case, one hundred and fifty firms represent the appropriate sample size and equal number of questionnaires was subsequently administered between August and October, 2009. However, one hundred and twenty (representing $80 \%$ ) questionnaires were returned and found useful for the exercise.

In evaluating the Law, questionnaires were administered on sampled firms of Estate Surveyors and Valuers. The questionnaire consisted of two sections. Section A was to obtain the respondents' bio-data, including details of their professional and academic qualifications, and post-qualification work experience. This was to determine the reliability or otherwise of their opinions. Section B consisted of questions to assist in obtaining information to determine the effects of the Law on Vision 20: 2020 sustainable housing delivery in Lagos State. The respondents were prompted to express opinions about the Law, its advantages and disadvantages, and adequacy or otherwise of the amount imposed as Land Use Charge. Other questions centered on acceptability of the basis of valuation stipulated by the Law, convenience of direct deductions by Estate Agents from rents due to the Landlords, and the short- and long- run effects of the Law on housing delivery in Lagos State. In addition, case studies were discussed to illustrate the effects tax on sustainable housing delivery in the study area.

In addition, a process of inference was used to consider the provisions of the Law in line with the aim of Vision 20:2020. The approach involved interpreting the Law devoid of its legal jargon and deductions subsequently drawn, while secondary data including literature on Nigeria's Vision 20:2020. Revenue allocation from Federal Government and internally-generated revenue in Lagos State were respectively obtained from the Federal Ministry of Finance and Lagos State Government Official websites.

\section{Relevant Provisions of the Land Use Charge Law (2001)}

The Land Use Charge Law (2001) came into force on $22^{\text {nd }}$ June 2001 and has twenty-four sections. It established that a land-based charge is payable on real properties situate in Lagos State, Nigeria with each Local Government Council Area empowered to levy and collect the charge for its area of jurisdiction as the Collecting Authority. Each Collecting Authority may delegate to the State, by written agreement, its functions with respect to collection of rates and the assessment of privately-owned houses or tenement for the purpose of levying the rate.

The Commissioner of Finance is by Law empowered to undertake or cause to be undertaken an assessment of chargeable properties in such areas as may be designated, and appoint property identification officers, qualified assessors and other persons considered necessary. The payment of the Land Use Charge which is to be based on annual capital sum is to be paid by the owner.

According to Section 5 (1) of the law, the formula for determining the annual amount payable is:

$\mathrm{LUC}=\mathrm{M} \times\{(\mathrm{LA} \times \mathrm{LV})+(\mathrm{BA} \times \mathrm{BV} \times \mathrm{PCR})\}$

where,

LUC $=$ annual amount of Land Use Charge in Naira;

$\mathrm{M}=$ the annual charge rate expressed as percentage of the assessed value of the property. The assessed value in this case may vary between owner-occupied residential and commercial properties at the discretion of the State Government. Commercial property refers to properties that are revenue-generating;

$\mathrm{LA}=$ the area of the land parcel in square metres;

$\mathrm{LV}=$ the average value of a land parcel in the neighborhood, per square metre in Naira;

$\mathrm{BA}=$ the total developed floor area of building on the plot of land in square metres, or the total floor area of apartment unit in a building where apartment has a separate ownership title; 
$\mathrm{BV}=$ the average value of medium quality buildings in the neighborhood, per square metre in Naira;

PCR =the Property Code Rate for the building and which accounts for the building being of higher or lower value than the average buildings in the neighborhood and which also accounts for the degree of completion of construction of the building.

In a nutshell, $(\mathrm{LA} \times \mathrm{LV})+(\mathrm{BA} \times \mathrm{BV} \times \mathrm{PCR})$ in Eqn. 1 is the assessed value of the property.

Sections 10 and 11 state that the Collecting Authority may declare any person including occupier of chargeable property to be property owner's agent and such person will become liable for payment of the charge on behalf of the owner from moneys due by him or becomes due by him for payment to the owner. The payment of the charge will become recoverable from the agent where the owner defaults in payment.

Penalties for delayed settlement of Land Use Charge are contained in Section 20 with the amount payable as penalty depending on the length of period the payment is delayed. Delay of between 45 and 75 days attracts $25 \%$ of the original Charge payable; between 76 to 105 days, 50\%; between 106 and 135 days, 100\%; while the property becomes liable to receivership after 135 days until outstanding taxes, penalties, and administrative charges are fully paid.

Essentially, the Law states that with effect from date that the Charge is levied on a property, all other laws that impose tax on properties (the Assessment Law, Land Rates Law, Neighbourhood Improvement Charge Law, and Tenement Rate Law) would cease to apply to such property. A supplement to the Law, known as Supplement to the Lagos State of Nigeria Official Gazette Extraordinary No. 41, Vol. 34 of $13^{\text {th }}$ December 2001 Part B stated the Annual Land Use Charge Rates payable on assessed value of a property to be: owner-occupied residential property $-0.5 \%$; industrial premises of manufacturing concerns $-0.5 \%$; residential property/commercial $0.65 \%$; commercial property used by occupier for business purposes - $1.75 \%$; owner-occupied pensioner's property, and family compounds are exempted from payment of Land Use Charge.

\section{The Indicative Parameters of Nigeria's Vision 20:2020}

The key goal for Vision 20:2020 is: "By 2020 Nigeria will be one of the 20 largest economies in the world able to consolidate its leadership role in Africa and establish itself as a significant player in the global economic and political arena"; while the key parameters to enhance the economic development goal are listed in Table 4.

As stated in the Concept Paper on Nigeria's Vision 20:2020, Nigeria's economic potential is well recognized as the biggest economy in the West African sub region with considerable resource endowment and coastal location. Very little of this potential has however been realized while previous efforts at planning and visioning were not sustained and the history of economic stagnation, declining welfare and social instability has undermined development for most of the past 30 years.

But in recent years, Nigeria has been experiencing a growth turn around and conditions seem right for launching onto a path of sustained and rapid growth, justifying its ranking amongst the N11 countries, which are the countries identified by Goldman Sachs to have the potential for attaining global competitiveness based on economic and demographic settings and the foundation for reforms already laid.

According to the Executive Summary of Vision 2020 Programme, rapid growth of the urban population has proceeded in an uncontrolled and unplanned manner giving rise to extensive slums and shanty towns. Various studies have estimated that there is shortage of 16 million housing units, and according to the World Bank, most people, probably over 80 per cent of the population, live in informal housing structures of varying degrees of permanence on land on which they have no ownership rights.

There are twenty-nine thematic areas for the National Technical Working Groups (NTWGs), these are Agriculture and Food Security, Business Environment and Competitiveness, Corporate Governance, Culture, Tourism and National Re-Orientation, Education, Employment, Energy, Environment and Sustainable Development, Finance, Foreign Policy, Governance, Health, Housing, Human Development, ICT, Judiciary and the Rule of Law, Manufacturing, Media and Communications, Mining and Steel Development, Niger Delta and Regional Development, Political System, Science, Technology and Innovation, Security, Small and Medium Entrepreneurships, Sports Development, Trade and Commerce, Transport, Urban and Rural Development, and Water and Sanitation.

The development process, methodology and milestones of Vision 20:2020 are to be implemented in three stages. Stage I which covers 2008 to 2010 is the building of solid foundation. In this stage, the first two components of the framework - the National Council on Vision 2020 and the National Steering Committee on V2020 was established by the end of April 2007. The NSC2020 undertook a review of all current strategy and related 
documents including the President's Seven Point Agenda and prepared a Statement of National Priorities forms the core elements of the country's development plans and budgets during the period 2008 to 2010 and constitute the foundation for V2020. The Statement of National Priorities sets specific targets to be achieved by 2010. The NSCV2020 also refined the V2020 framework and developed guidelines for the V2020 development process.

Stage II is to focus on achieving the millennium development goals (MDGs) en route to V2020 would be attained between 2011 and 2015. The focus in this stage is to achieve all the goals by year 2015 as a general guide with stakeholders determining their areas of focus in accordance with their progress. Stage III is to focus on becoming a top 20 economy by year 2020 and covers the period from year 2015 to 2020. In this stage, the National Steering Committee is expected to develop detailed key goals and targets to be met in order to achieve convergence with the projected positions of the top 20 economies.

\section{Analysis and Discussion}

Attempt is made in this section to determine the effects of the Land Use Charge on housing delivery under the Vision 2020 and proffer answers to the research problems stated earlier in this paper in order to attain the stated aim. In doing so, the respondents' opinions on each of the questions posted were analyzed and deductions made therefrom.

\subsection{Respondents' Bio-data}

In determining the reliability of the respondents' opinions, their academic and professional qualifications and work experience were examined. As shown in Table 5, out of one hundred and twenty respondents, $83.33 \%$ have the first degree (B.Sc.); about $67 \%$ are Associates of the Nigerian Institution of Estate Surveyors and Valuers, while about $29 \%$ are Fellows; and about $4 \%$ of the respondents also belong to the Royal Institute of Chartered Surveyors. In respect of work experience, 115 (about 21\%) have been practicing for more than ten years. This implies that the respondents possessed the capacity to understand the questions and that their opinions and the research findings are reliable.

\subsection{Defaults in Rent and Imposition of Penalties}

Out of one hundred and twenty respondents, $90 \%$ commended the consolidation of multiple taxes previously payable on properties into the Land Use Charge. However, 95\% considered penalty payable for delayed settlement of the Charge to be excessive since property owners are expected to settle the Charge within 135 days before the property becomes liable to receivership, whereas tenants fall into arrears of rent for over six months as shown in Table 6. More than ninety percent of the respondents claimed that tenants usually fall into arrears of rents for a period of six months and more whereas the Law expects that the amount of Charge should be paid within 135 days. It is conclusive that the Law ignored delays and defaults in rent payments by the tenants while fixing maximum period within which to settle the tax. It is also conclusive that penalties for delay in settlements of the Charge without due consideration to default by tenants is highly punitive on the owner since property tax is expected to be paid from the rents received by the property owners.

\subsection{Advantages and Disadvantages of the Land Use Charge Law}

In determining the advantages and disadvantages of the law, the respondents were given opportunities to select as many options as they deem applicable. From Table 6 , out of 120 respondents, $83.3 \%$ of respondents considered making agents liable for settlement of the Land Charge a disadvantage; $87.5 \%$ regarded the imposition of penalties for delayed settlement as a disadvantage while all respondents opined that liability to receivership after four to five months delay in settlement is a disadvantage. Furthermore, in determining the respondents' opinion about the use of capital value as basis of tax, about $92 \%$ of respondents considered the basis as a disadvantage. On the other hand, out of one hundred and twenty respondents, about $96 \%$ stated that the law will prevent multiple taxes being levied on properties; while about $83 \%$ were of the opinion that it would prevent evasion of tax payment.

\subsection{Declaration of Occupiers as Agent of Owners}

The Law provides that any occupier of chargeable property could be declared to be the agent of the owner and becomes liable for payment of the charge on behalf of the owner from moneys due by him or becomes due by him for payment to the owner, and that the payment of the charge will become recoverable from the Agent where the owner defaults in payment. As shown in Table 7, out of One hundred and twenty respondents, 115 representing $96 \%$ were of the opinion that the law is disadvantageous and that it would create a lot of challenges to Estate Surveyors and Valuers acting as Property Manager. This is because the Law holds occupier or Agents of owners vicariously liable for the misdemeanor of the Principal. This provision appears to be vindictive. 


\subsection{Basis of Tax Assessment}

As provided by the Law, the basis of calculation of the land use charge is the capital value. In determining the fairness or otherwise of the basis, respondents' opinion were sought. The respondents were given three options to guide them in their decision. The options were: net annual rental income, gross rental income, and capital value bases. Out of 120 respondents, 117 (representing 97.50\%) were of the opinion that the net annual rental value basis is appropriate as shown in Table 8.

\subsection{In respect of Fairness of the Tax}

In determining the "reasonableness" of the formula and "fairness" of the basis of determining the Land Use Charge, Case Study of a property on which the tax has been levied was used. The property is at No 10 Alhaji Bashy Mustapha Street, Oladipo-Oshodi, Lagos. It is a residential property with the front-wing affording accommodation on two floors for one family occupation and the rear-wing consists of 2No two-bedroom flats. The structure is set within fenced $669.05 \mathrm{~m}^{2}$ curtilage and the total rent paid by the sitting tenants is $\mathrm{N} 470000$ p.a. paying therefrom $10 \%$ as Management fees. The property was valued by officials of LUC Office at N9.6 million. Land in the neighbourhood is selling for $\mathrm{N} 5$ million, and the annual charge rate for type of property is $0.5 \%$. The appropriate charge rate payable in the current year will be calculated as follows:

Recall: $L U C=M x\{(L A x L V)+(B A \times B V \times P C R)\}$

$L U C=0.005 \times\{N 5000000+[N 4600000 \times 1.0]\}$

$L U C=0.005 \times\{N 9600000\} \times 1.0$

$L U C=N 48000$ p.a. This amount represents $11.4 \%$ of the net rent due to the owner.

Assuming that the property is a commercial user with similar details but the built-up area being $60 \%$ of the site area, and prevailing rental value is N550 000 p.a. The corresponding annual charge rate for the commercial property according to the Law is $1.75 \%$.

The appropriate charge rate payable in the current year will be calculated as follows:

$L U C=1.75 \% \times\{N 5000000)+(N 4600000 \times 1.0)\}$

$L U C=0.0175 \times\{N 9600000\}$

$L U C=N 168000$. For commercial user, the amount represents $35.8 \%$ of the net rent due to the owner.

The calculation appears straightforward but its components (rate payable and property code rate) are entirely at the discretion of the officials. The implication of this provision is that no property owner is sure of the amount of Charge to be paid in every succeeding year. This negates the principles of fair and equitable tax which expects that the amount of rates should be certain. Calculation of tax liability at the discretion of government official makes the Law prone to abuse by political office-holders and the amount payable becomes uncertain.

The statutory formula assumes that all properties are homogenous whereas no two properties are the same in terms of specific location, road network, accessibility, demand and supply, and state of repairs. The use of uniform Property Code Rates (PCR) therefore negates uniqueness of each property. Also, the formula implies that the value of land will be added to estimated value of building. It appears to be an 'adulterated' contractor's method of valuation. It involves value of land (LA x LV i.e. area of land multiplied by average value per square metre) to which is added value of the improvements on site (BA x BV). The implication is that both the bare-site and physical development on it are being taxed, whereas the norm is that taxes are expected to be levied on the owner of an income-generating property and not on the property per se. By charging tax on capital value, all annual periodic payments now and in perpetuity or for as long as a lease endures (if a leasehold interest) is being compounded far into the future and owners are made to pay the amount now. This is contradictory. If the Land Use Charge is to be paid annually, then the basis for calculation should be the net annual rent. This is because capital value is actually the net annual value compounded in perpetuity or over the term (if leasehold). Why should a landlord pay the Land Use Charge as if he is 'selling' his property annually? The only condition by which capital value may be used as basis for taxation is when it equals net annual value capitalized at the relevant rate of interest to produce an equivalent base for taxation as net annual value.

\subsection{Analysis of Respondents' Opinion on Effects of Land Use Charge}

The respondents were given three options of the effects of Land Use Charge Law; these were short-, long-, and combination of the two effects. Out of 120 respondents, about $4 \%$ were of the opinion that the effect would be in the short-run only; about $13 \%$ opined that the effects would be in the long-run effects only; while $83 \%$ stated that the effects would be in both short- and long- run as stated in Table 9 


\subsection{Theoretical Explanation of the Effects of Land Use Charge Law on Vision 20:2020}

The overall effect of the Land Use Charge Law on Vision 20:2020 housing thematic area may be determined by considering the short- and long- run effects on rent and quality of housing that will be available in the open market. Figs. 3 and 4 illustrate the short- and long- run effects of LUC on quality of available housing. In the short-run, the initial rent will be OV. If Land Use Charge is imposed on the landlord, the net rent will drop to $\mathrm{OV}_{1}$ and demand curve shifts to $D_{1}$. In the short-run, landlords will receive the net rent which falls from $O V$ to $O V_{1}$. The landlord will initially bear the incidence in anticipation of making up through increase in subsequent rents. Having managed to bear the short-run incidence, the landlord will most likely react and cause long-run effects in terms of increased rent and lower quality of properties available in the open market.

In other words, in the short-run, the incidence of Land Use Charge will cause reduction in the net rent that is due to the owners while the quality of housing will remain constant. However, the situation will change in the long run as shown in Fig. 4. In long run, supply of quality properties will be more elastic and some of the burden will be passed to the tenant. $\mathrm{VV}_{2}$ of the rate of burden will be passed to the tenant and $\mathrm{V}_{1} \mathrm{~V}$ backwards to the property owner. The total rate being $\left(\mathrm{OV}-\mathrm{OV}_{1}\right) \times \mathrm{OM}$; and the quality and available rented housing units will decrease from $\mathrm{OM}$ to $\mathrm{OM}_{1}$. The incidence of the Land Use Charge will shift in the long run in terms of increase in rent $\left(\mathrm{OV}_{2}\right)$ from $\mathrm{OV}_{1}$. Expectedly, the tenants may react by defaulting in rent payments; the amount available for maintenance will decrease to $\mathrm{OM}_{1}$ to $\mathrm{OM}$. Furthermore, the following scenario may occur: parties will resort to litigations - landlords will move to eject the tenants; tenants will apply to court for landlords' compliance with the provisions of the existing Rent Control and Recovery of Residential Premises Edict and other Laws that regulate rent payable on residential properties in Lagos State. There may be an influx of litigations from landlords/tenants on one hand, and government/property owners on the other.

Also, in the long run, the incidence of the Charge will be passed on to the tenant through rent increases while tenants may most likely be unable to pay; subsequently, the quality of housing will reduce. High incidence of Charge will most likely force owners to transfer it to the tenant, the effect is that the occupiers of housing units in the State that has already witnessed high occurrence of informal housing will be worse off in the long run. The overall effect is that shortage of sixteen million housing units identified as a problem in the Executive Summary of Vision 20:2020 will be aggravated by the long run effects of the Land Use Charge. The objective of Vision 20:2020 to ensure availability of good quality housing may therefore not be realized.

Furthermore, questions were asked to elicit opinions of the respondents and enable comparison with the theoretical explanation of the long-run effects. Details of their opinions are shown in Table 10. Out of one hundred and twenty respondents, $25 \%$ were of the opinion that in the long run, the burden of the Land Use Charge would be the transferred to the tenants; about $21 \%$ were of the opinion that there would be an increase in rent of residential properties in the area, about $8 \%$ suggested that there would be an increase in default payment of rent in the area; while $19 \%$ opined that litigation between owners and tenants would increase. This could be a result of increase in the transfer of tax burden from the owners to the tenants. Default in rent payment could occur which would lead to increased litigation between tenants and owners. Other opinions that were expressed include that litigation between government and owners or their agents would increase welfare of tenants would decrease; relocation of developers to neighboring state, and decrease in stock of quality housing will be the long run effects. On the other hand, $25.2 \%$ of the tenants opined that rent would increase; $8 \%$ stated that there would be increase in litigations involving owners and tenants to enforce the law; and $17.5 \%$ were of the opinion that rates of defaults in rent payment would increase; while about $23 \%$ stated that stock of quality housing would decrease in the long-run.

The implication of this finding is that the burden of property tax will be borne by the tenants who in the long-run may not meet the obligation of payment, and when rents are not paid promptly the amount available for maintenance and regularity of repairs of existing housing stock will drastically reduce, the overall effect is that generations yet unborn will suffer the present neglect of the housing stock if the trend continues.

\section{Recommendations and Conclusion}

The capital value basis of calculating the Land Use Charge is inappropriate; the appropriate basis of determining fair and equitable charge is the investment method that considers the open market rental value per annum after deducting for outgoings and appropriate rate per naira applied.

The Lagos State Government is justified to raise funds through property tax as applicable all over the world to finance physical and infrastructural developments and make life meaningful to the citizens. The Law should however be amended to make the net annual rental income as the basis of valuation.

The Law neither provided nor gave allowance for risk of tenants' default in rent payment which has become 
common tales amongst Estate Surveyors and Valuers. The penalties imposed for delaying settlement of the Charge is therefore too harsh against the background of tenants falling into arrears of rent payment of up to twelve months or more. It becomes more difficult for the owners to settle the Charge as soon as it is demanded when tenants usually fail to pay rent promptly. It will therefore be counter-productive for Government to impose penalty on owners or Estate Surveyors for late settlement of Land Use Charge. If Lagos State Government insists on prompt payment of the Charge, there should be provisions to protect the owners against rent defaults by tenants while penalty should be $10 \%$ flat per annum after payment has been delayed for more than six months.

It is also recommended that Estate Surveyors and Valuers should not be held liable to make deductions for the Charge from rents collected on behalf of their clients; rather the Lagos State Government should appoint Estate Surveyors and Valuers to determine the appropriate annual values, collect and remit the Charge to the Government.

In conclusion, to ensure a sustainable housing delivery in Nigeria, especially in Lagos State, the Vision 20:2020 housing theme must be attainable through tax policy that is people oriented, and by encouraging private investment in provision of housing. This will not only satisfy the present generation but will ensure that quality of housing to be bequeathed to future generation is sustained.

\section{References}

Ajayi, C. A. (1998). Property Investment Valuation and Analysis. Ibadan: De-Ayo Publications.

Bartlett, J. E., J. W. Kotrlik, and C. C. Higgins. (2001). Organizational Research: Determining Appropriate Sample Size in Survey Research. Information Technology, Learning, and Performance Journal, 19, 1, Spring 2001.

Bird, R. M. and P.-P. Gendron, (2000). "CVAT, VIVAT and Dual VAT; Vertical 'Sharing' and Interstate Trade," International Tax and Public Finance, 7: 753-61.

Clark, W. C. (1989). Managing Planet Earth. Scientific American, 261(3): 47-54.

Collins, C. (2003). Infrastructure. Advanced Learner English Dictionary, $4^{\text {th }}$ ed. London: Harper Collins Publisher.

Concept Paper on Vision 20:2020 at http://www.nv2020.org/?Concept accessed on Friday, $1^{\text {st }}$ January, 2010.

Costanza, R., Daly, H. E., and Bartholomew, J. A. (1991). Goals, Agenda and Policy Recommendations for Ecological Economics. In R. Costanza (Ed.), Ecological Economics: The Science and Management of Sustainability: 1-20. New York: Columbia University Press.

Denson, B. N. (2009). Ad Valorem Tax at http://www.athensclarkecounty.com/ tc/adval.htm, official website of Athens-Clarke County, State of Georgia, USA accessed $24^{\text {th }}$ June, 2010

Ehtisham, A. and Stern, N. (1991). The Theory and Practice of Tax Reform in Developing Countries. Cambridge University Press.

Emeni, K. F. (2000). Taxation in Financial Planning and Decision-making. Nigerian Taxation - Journal of the Chartered Institute of Taxation of Nigeria. 3 (1 and 2), January - June, 37 - 38.

Gore, A. (1992). Earth in Balance: Ecology and the Human Spirit. New York: Houghton Mifflin.

Harriss, C. L. (2009). The Economic Effects of Today's Property Tax, in www.groundswellusa.org/feet7.htm; accessed 7 December 2009.

Harvey, J. (2000). Urban Land Economics, $5^{\text {th }}$ Ed. NY

Ifediora, B. U. (2005). Valuation Mathematics for Valuers and Other Financial and Investment Analysis. Enugu: Immaculate Publications Ltd. ISBN 978-036-720-9.

Johnson, T., Davis, K., and Shapiro (2005). Modern Methods of Valuation of Land Houses and Buildings. London: Estates Gazette.

Jones, D., Lyon Reid, K., and Gilbert, D. (2003). Sustainability Assessment Considering Asset and Building Life Cycles. In Kenneth, K. (2002). IT for the Common Man: Lesson from India. Delhi; New York: Oxford University Press.

Kalu, I. U. (2001). Property Valuation and Appraisal. Owerri: BON Publications.

Keen, M. and S. Smith. (2000). "Viva VIVAT!" International Tax and Public Finance, 7: 741-51.

Lagos State Official Website at http://www.lagosstate.gov.ng/index.php?page=subpage\&spid $=12 \& m n u=$ null, 
accessed December 11, 2009.

Lean, W. and B. Goodall (1977). Aspects of Land Economics. London: The Estates Gazette Limited.

Lee, K. N. (1993). Greed, Scale Mismatch and Learning. Ecological Applications, 3(4): 560-564.

McLure, C. E. (2000). Implementing Sub-national VATs on Internal Trade: The Compensating VAT (CVAT). International Tax and Public Finance, 7: 723-40.

Millington, A. F. (1982). An Introduction to Property Valuation 7th Ed. The Pitman Press, Bath.

Newell, M. (1977). An Introduction to the Economics of Urban Land Use. London: The Estate Gazette Limited.

NIESV (1985). Guidance Notes on Property Valuation. $1^{\text {st }}$ Ed. Feb. 1985. Lagos: The Nigerian Institution of Estate Surveyors and Valuers.

NIESV (2009). Directory of Members and Registered Firms $7^{\text {th }}$ Ed. January 2009. Lagos: Climax Communications Limited.

Ogbuefi, J. (2004). Comparative Property Rating and Taxation. Enugu: Institute for Development Studies. ISBN 9752409589 .

Oklahoma Ad Valorem Tax Laws Prepared by Oklahoma Tax Commission Ad Valorem Tax Division Publication No. 07-01-TXLAW-01.

Olusegun, K. (2003). Fundamentals of Real Estate Taxation. Lagos: Climax Communications Ltd, 4.

Richmond, D. (1975). Introduction to Valuation. London: The MacMillan Press Ltd.

Rolston, H. (1994). Conserving Natural Value. New York: Columbia University Press.

Serra, J. and Afonso, J. (1999). Fiscal Federalism Brazilian Style: Some Reflections. Paper presented to Forum of Federations, Mont Tremblant, Canada, October 1999.

Sharma, Chanchal Kumar. (2005). Implementing VAT in India: Implications for Federal Polity. Indian Journal of Political Science, LXVI (4): 915-934.

Silvani, C. and Paulo dos Santos. (1996). Administrative Aspects of Brazil's Consumption Tax Reform. International VAT Monitor, 7: 123-32.

Stern, P. C., Young, O. R., and Druckman, D. (Eds.). (1992). Global Environmental Change: Understanding the Human Dimensions. Washington, DC: National Academy Press.

Tait, A. A. (1988). Value Added Tax: International Practice and Problems. Washington: International Monetary Fund.

Taubman, P. (1965). The Effects of Ad Valorem and Specific Taxes on Prices. The Quarterly Journal of Economics, Vol. 79, No. 4 (Nov., 1965), 649-656 Published by: The MIT Press Stable URL: http://www.jstor.org/stable/1880657Accessed: 30/06/2010 07:26.

Tesfay, A. (2008). Infrastructure Development Enhances National Development

Shaebia at http://www.shaebia.org/artman/publish/article_5480.shtml accessed on Tuesday, $1^{\text {st }}$ July 2008 at 7p.m.

Thacker, S. (2009). Taxation in the Gulf: Introduction of a Value Added Tax. Michigan State Journal of International Law, Vol. 17, Issue 3, p. 721, 2008-2009.

Uniform Standard of Professional Appraisal Practice. (2008-2009). Appraisal Standards Board, the Appraisal Foundation Published in the United States of America. ISBN: 978-0-9798728-0-8. 
Table 1. Population of Lagos State by Local Government Area as at 2006

\begin{tabular}{|c|c|c|c|}
\hline Local Government Council Area & Male & Female & Total \\
\hline Agege & 564239 & 468825 & 1033064 \\
\hline Ajeromi-Ifelodun & 723644 & 711651 & 1435295 \\
\hline Alimosho & 1099656 & 947370 & 2047026 \\
\hline Amuwo-Odofin & 301012 & 223959 & 524971 \\
\hline Apapa & 264728 & 257656 & 522384 \\
\hline Badagry & 187427 & 192993 & 380420 \\
\hline Epe & 153360 & 170274 & 323634 \\
\hline Eti-Osa & 460124 & 523391 & 983515 \\
\hline Ibeju-Lekki & 49613 & 49927 & 99540 \\
\hline Ifako-Ijaiye & 380112 & 364211 & 744323 \\
\hline Ikeja & 328778 & 319942 & 648720 \\
\hline Ikorodu & 364207 & 324838 & 689045 \\
\hline Kosofe & 527539 & 407075 & 934614 \\
\hline Lagos-Island & 461830 & 398019 & 859849 \\
\hline Lagos-Mainland & 326433 & 303036 & 629469 \\
\hline Mushin & 684176 & 637341 & 1321517 \\
\hline Ojo & 507693 & 433830 & 941523 \\
\hline Oshodi-Isolo & 514857 & 619691 & 1134548 \\
\hline Somolu & 517210 & 507913 & 1025123 \\
\hline Surulere & 698403 & 575959 & 1274362 \\
\hline Total & $\begin{array}{lll}9 & 115 & 041\end{array}$ & $\begin{array}{lll}8 & 437 & 901\end{array}$ & $\begin{array}{lll}17 & 552 & 942\end{array}$ \\
\hline
\end{tabular}

Source: Official Website of Lagos State Government, 2009

Table 2. Revenue Allocation to Lagos State (2004 -2009)

\begin{tabular}{lllllrrr}
\hline S/ & Month & $\mathbf{2 0 0 4}$ & $\mathbf{2 0 0 5}$ & $\mathbf{2 0 0 6}$ & $\mathbf{2 0 0 7}$ & $\mathbf{2 0 0 8}$ & \multicolumn{1}{c}{$\mathbf{2 0 0 9}$} \\
\hline 1 & January & 1762480 & 2449451 & 1934740 & 3051532 & 4148073 & 5423179 \\
2 & Februar & 1896924 & 2491794 & 2583657 & 5187955 & 6240849 & 4298088 \\
3 & March & 1877155 & 2501109 & 2483416 & 3438722 & 5707396 & 6138148 \\
4 & April & 1788954 & 2296788 & 2247254 & not available & 7878024 & 4649052 \\
5 & May & 2241955 & 2210913 & 2301051 & 3855086 & 5732169 & 5671950 \\
6 & June & 2301088 & 2739812 & 5491729 & 4484250 & 8364587 & 5528747 \\
7 & July & 2667299 & 2195772 & 2822753 & 5057883 & 5866578 & not available \\
8 & August & 1835288 & 2736586 & 3367236 & 3861714 & 5829699 & 5655413 \\
9 & Sept & 1793245 & 2088187 & 6676235 & 4596404 & 5124073 & 5461024 \\
10 & October & 1673104 & 2245589 & 3089848 & 4193327 & 5879400 & 5599502 \\
11 & Nov & 2391761 & 2520383 & 3167773 & 4375938 & 6087626 & 5872696 \\
12 & Dec. & 2749801 & 2574943 & 2720283 & 4487946 & 5672784 & not available \\
\hline \multicolumn{1}{l}{ Total } & $\mathbf{2 3 1 4 3 7 7 3}$ & $\mathbf{2 6 7 5 4 5 4 4}$ & $\mathbf{2 9 1 1 9 8 9 8}$ & $\mathbf{4 6 5 9 0 7 6 2}$ & $\mathbf{3 3 7 4 5 8 1 6}$ & $\mathbf{3 2 ~ 0 0 0 ~ 0 0 0}$ \\
Annual \% & - & $\mathbf{1 5 . 6}$ & $\mathbf{8 . 8}$ & $\mathbf{6 0}$ & $\mathbf{( 2 7 . 6 )}$ & $\mathbf{( 5 . 2 )}$ \\
increase & & & & & &
\end{tabular}

Source: Federal Ministry of Finance, Abuja 
Table 3. Comparison of Sources of Revenue to Lagos State Government

\begin{tabular}{lrrrr}
\hline Source of Revenue & \multicolumn{2}{c}{$\mathbf{2 0 0 8}$} & \multicolumn{2}{c}{ Years } \\
& $\mathbf{2 0 0 7}$ & \multicolumn{2}{c}{$\mathbf{2 0 0 9}$} \\
\hline Internally generated & 119248307062.35 & 216033444054.72 & 288963602199 \\
& $(71.91 \%)$ & $(86.49 \%)$ & $(90.03 \%)$ \\
Federal Allocation & & & 32000000000 \\
& 46590762257.55 & 33745816069 & $(9.97 \%)$ \\
\hline Total & $(28.09 \%)$ & $(13.51 \%)$ & 320963602199 \\
& 165839069319.90 & 249779260123.72 & $(100 \%)$ \\
\hline
\end{tabular}

Table 4. Key Parameters and Goals of Vision 20:2020

\begin{tabular}{ll}
\hline Parameter & Goal \\
\hline Polity & By 2020 the country will be peaceful, harmonious and a stable democracy. \\
Macro-Economy & A sound, stable and globally competitive economy with a GDP of not less than $\$ 900$ \\
& billion and a per capita income of not less than $\$ 4000$ per annum. \\
Infrastructure & Adequate infrastructure services that support full mobilization of all economic sectors. \\
Education & Modern and vibrant education system which provides for every Nigerian the opportunity \\
and facility to achieve his maximum potential and provides the country with adequate and \\
competent manpower. \\
Health & $\begin{array}{l}\text { A health sector that supports and sustains life expectancy of not less than } 70 \text { years and } \\
\text { reduces to the barest minimum the burden of infectious diseases such as malaria, }\end{array}$ \\
Hgriculture & AIV/AIDS and other debilitating diseases. \\
& A modern technologically enabled agricultural sector that fully exploits the vast \\
& agricultural resources of the country ensures national food security and contributes \\
significantly to foreign exchange earnings. & A vibrant and globally competitive manufacturing sector that contributes significantly to \\
Manufacturing & GDP with a manufacturing value added of not less than $40 \%$
\end{tabular}

Source: Vision 20:2020 Official Website 
Table 5. Details of Respondents' Bio-data

\begin{tabular}{llrr}
\hline Qualification/Experience & Option & Number & Percentage \\
\hline Academic & B.Sc./HND & 100 & 83.33 \\
& M.Sc. & 20 & 16.67 \\
Professional & Ph.D. & 0 & 0 \\
& Associate NIESV & 80 & 66.67 \\
Work Experience & Fellow NIESV & 35 & 29.17 \\
& RICS Membership & 5 & 4.16 \\
& Less than 5 years & 0 & 0 \\
& 6-10 years & 5 & 4.17 \\
& 11 - 15 years & 70 & 58.33 \\
& 16-20 years & 20 & 16.67 \\
& Above 20 years & 25 & 20.83 \\
\hline
\end{tabular}

Table 6. Default Rates amongst Tenants in Lagos Metropolis

\begin{tabular}{llrr}
\hline S/N & Period of Defaults & Number of Respondents & Percentage \\
\hline 1. & $1-6$ months & 12 & 10.00 \\
2. & Between 7 and 12months & 86 & 71.67 \\
3. & More than 12 months & 22 & 18.33 \\
\hline Total & $\mathbf{1 2 0}$ & $\mathbf{1 0 0 . 0 0}$ \\
\hline
\end{tabular}

Table 7. Respondents' Opinions on Advantages and Disadvantages of the Law

\begin{tabular}{llrr}
\hline S/N & \multicolumn{1}{c}{ Options } & \multicolumn{2}{c}{ Number of Respondents } \\
\cline { 3 - 4 } & & Advantageous & Disadvantageous \\
\hline 1. & Making the agents liable & $20(16.67 \%)$ & $100(83.33 \%)$ \\
2. & Imposition of penalties for delayed settlement & $15(12.50 \%)$ & $105(87.50 \%)$ \\
3. & Liability to receivership after four to five months & $0(0.00 \%)$ & $120(100 \%)$ \\
4. & Using annual capital sum as the basis for the amount & $10(8.33 \%)$ & $110(91.67 \%)$ \\
& to be paid. & & $5(4.17 \%)$ \\
5. & Prevention of multiple taxes from being levied on & $115(95.83 \%)$ & \\
& $\quad$ same properties & $100(83.33 \%)$ & $20(16.67 \%)$ \\
6. & Prevention of tax evasion & &
\end{tabular}

Table 8. Respondents' Opinion about Basis of Land Use Charge

\begin{tabular}{lrr}
\hline Option & Number of Respondents & Percentage \\
\hline Net Annual Value & 117 & 97.50 \\
Gross Annual Value & 2 & 1.67 \\
Capital Value & 1 & 0.83 \\
\hline Total & $\mathbf{1 2 0}$ & $\mathbf{1 0 0 . 0 0}$ \\
\hline
\end{tabular}

Table 9. Respondents' Opinion of Effects of Land Use Charge on Housing Delivery

\begin{tabular}{lrr}
\hline Option & Number of Respondents & Percentage \\
\hline Short-run only & 5 & 4.17 \\
Long-run only & 15 & 12.50 \\
Short- and Long- run & 100 & 83.33 \\
\hline Total & $\mathbf{1 2 0}$ & $\mathbf{1 0 0 . 0 0}$ \\
\hline
\end{tabular}


Table 10. Long-run Effect of the Land Use Charge

\begin{tabular}{rlr}
\hline $\mathbf{S} / \mathbf{N}$ & \multicolumn{1}{c}{ Option } & \multicolumn{1}{c}{$\begin{array}{c}\text { Number of } \\
\text { (with \% in parenthesis) }\end{array}$} \\
\hline 1 & tax burden will be passed to tenants & $30(25 \%)$ \\
2 & increase in rent & $25(20.83 \%)$ \\
3 & default in rent payment will increase & $10(8.33 \%)$ \\
4 & increased litigation btw owners and tenant & $10(8.33 \%)$ \\
5 & increased litigation between government & $5(4.17 \%)$ \\
& and owners/agents & \\
6 & tenants will be worse off than before & $5(4.17 \%)$ \\
7 & relocation of developers to neighbouring states & $3(2.50 \%)$ \\
8 & decrease in land and property value & $5(4.17 \%)$ \\
9 & decrease in stock of quality housing & $27(22.5 \%)$ \\
\hline Total & & $\mathbf{1 2 0}(\mathbf{1 0 0 . 0 \% )}$ \\
\hline
\end{tabular}

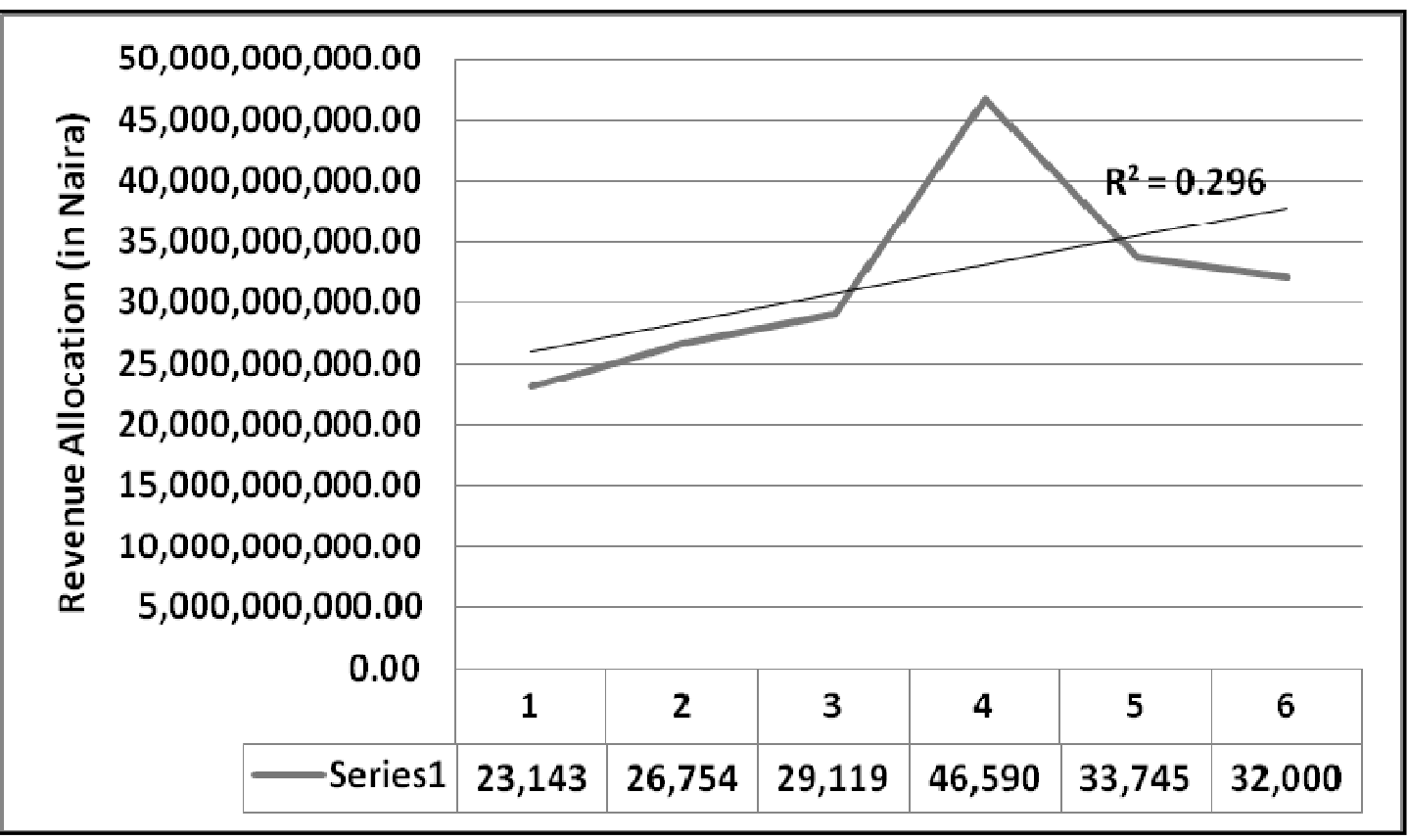

Figure 1. Trend of Federal Revenue Allocations to Lagos State (2004 - 2009) 


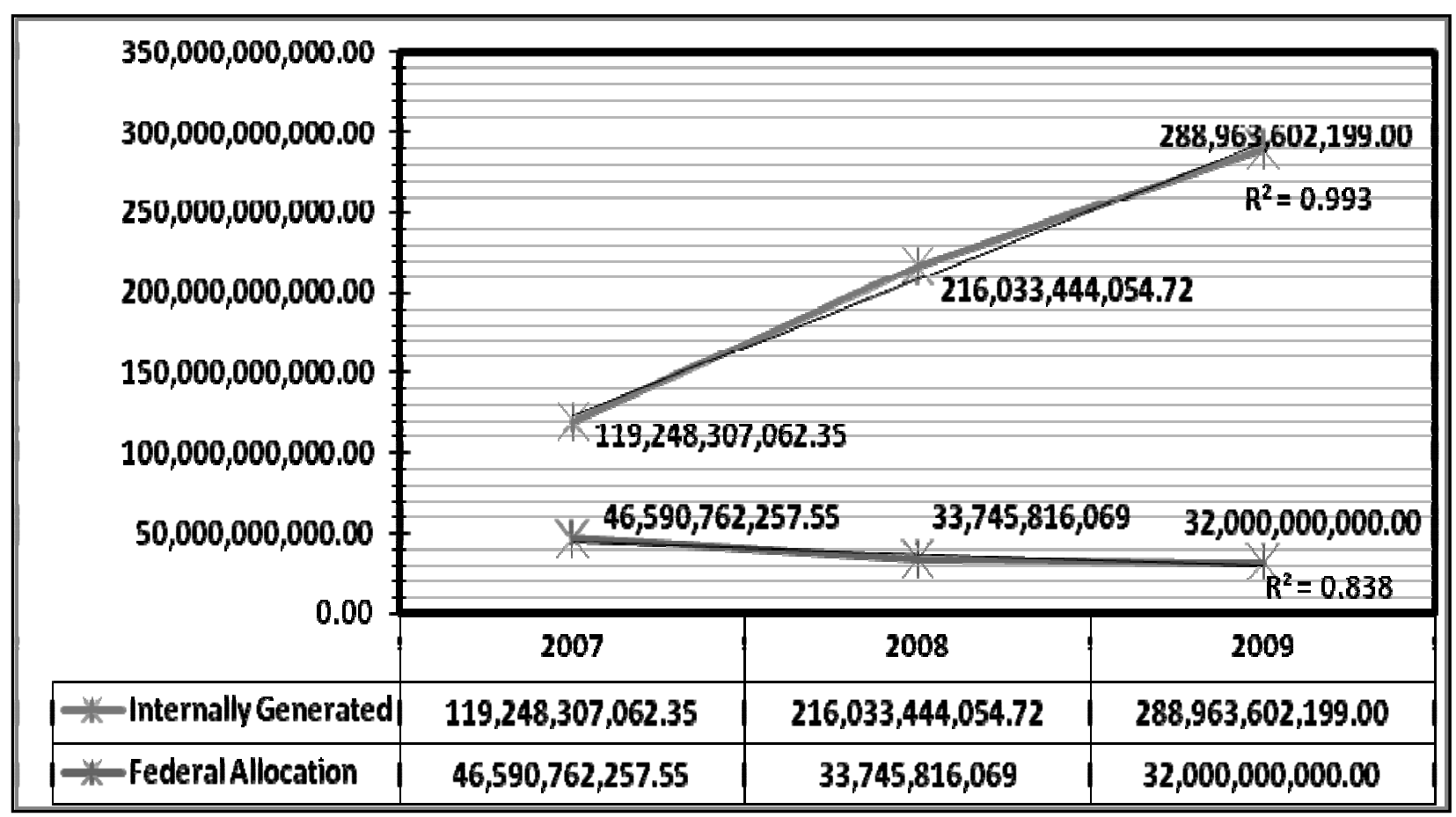

Figure 2. Trends in Combined Internally-generated and Federal Allocations (2007 - 2009)

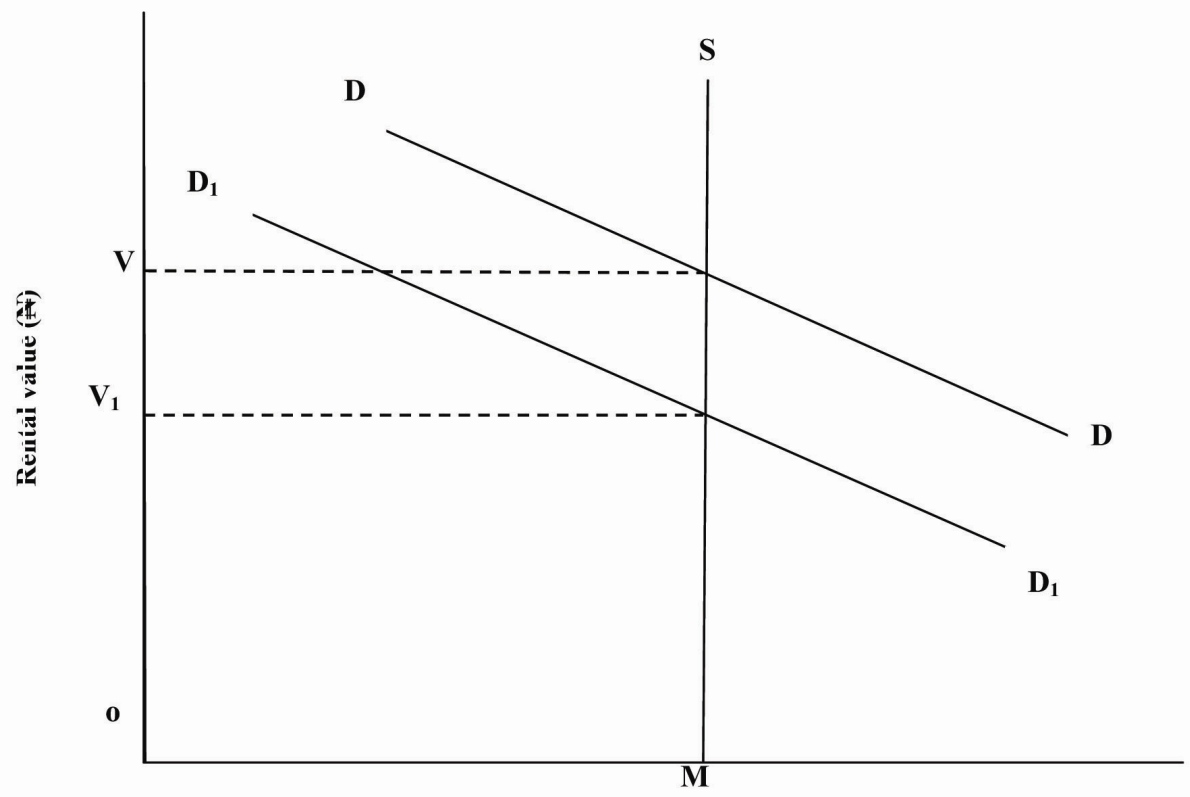

Quality of property (quantity)

Figure 3. Short-run Effect of Land Use Charge on Housing Quality 


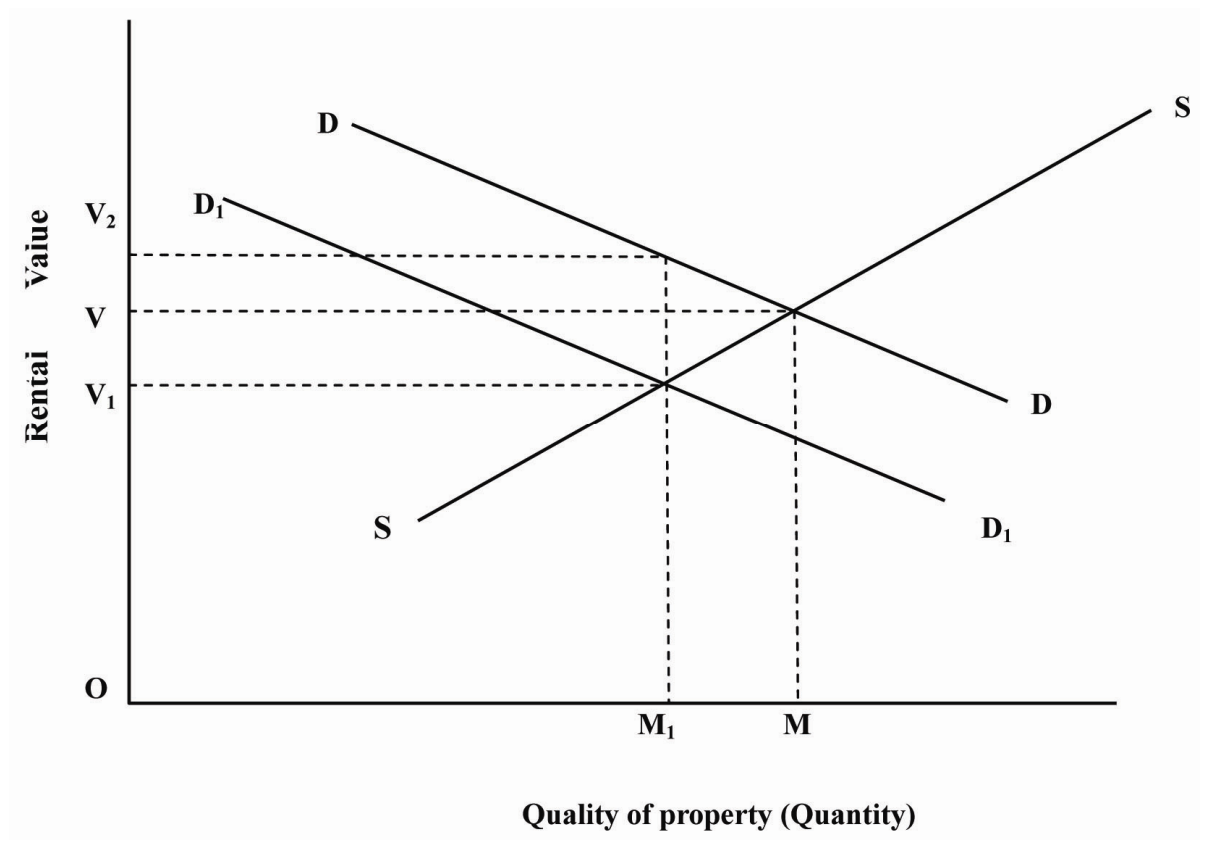

Figure 4. Long-run Effect of Land Use Charge on Housing Quality

\title{
APPENDIX
}

\author{
DEPARTMENT OF ESTATE MANAGEMENT \\ COLLEGE OFVSCIENCE \& TECHNOLOGY \\ COVENANT UNIVERSITY, OTA, OGUN STATE \\ QUESTIONAIRE
}

ON

\section{Effects of Property Tax on Sustainable Housing Delivery in Lagos State, Nigeria}

\section{Dear NOBLE Colleague}

This questionnaire is designed to obtain information to assist in assessing the short-and long-run effects of the land use charge law in 2001 on housing delivery in Lagos State. The aim is to come up with suggestions that could influence policy decision on the law.

We assure you that the information provided will be used strictly for research purpose and kept confidential with the findings, however, made available to all professional colleagues.

Kindly complete the blank space and put marks in the appropriate boxes as applicable.

Grateful for your kindness to complete the questionnaire..

Thank you.

Olawande Oni and Ayodele Ajayi

08023122014

\section{SECTION A}

1. Location of your OFFICE:

2. Gender: 

(a) Male
(b) Female

[ ]

3. Qualifications:

(a) Professional

(i) Probationer [ ]

(ii) ANIVS [ ]

(iii) FNIVS

(iv) Other professional qualification, please state:

(b) Academic Qualification:
(i) $\quad$ B.Sc
(ii) M.Sc
(iii) Ph.D
(iv) HND
(v) OND
(vi) Other academic qualifications, pls. state:

4. Post Qualification Work Experience as Estate Surveyor:
(a) Less than 5 years
(b) 5-10 years
(c) $10-15$ years
(d) 15-20 years
(e) Above 20 years
[ ]

\section{SECTION B}

1. Have you ever heard about the Land Use Charge (LUC)? Please select one
(a) Yes [ ]
(b) No [ ]

2. If yes, how will you describe the (LUC)? Select one portion
(a) It is variant of the Land Use Act
(b) It is a form of property tax
(c) It a levy for use of land, similar to ground rent [ ]
(d) Other, please state:

3. What basis of annual tax assessment will you recommend? Select one option
(a) Net annual rental income
(b) Gross rental income
(c) Capital value
(d) Don't know

$\left[\begin{array}{ll}{[} & ] \\ {[} & ] \\ {[} & {[}\end{array}\right]$

4. Do you agree that it is the net income receivable from a property that should be taxed? Select one option
(a) I strongly agree
(b) I agree
(c) A neither agree nor disagree
(d) I disagree
(e) A strongly disagree

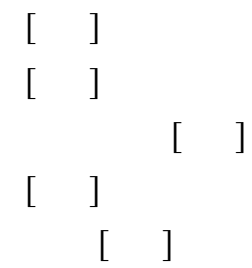

5. Do you agree that it is the capital value of a property that should be taxed on annual basis? Select one option: 
$\begin{array}{llll}\text { (a) strongly agree } & {[} & & \\ \text { (b) I agree } & {[} & & \\ \text { (c) A neither agree nor disagree } & & & {[} \\ \text { (d) I disagree } & {[} & ] & \\ \text { (e) A strongly disagree } & {[} & {[}\end{array}$

6. Do you think that imposition of tax has effects on housing delivery?

(a) yes, it has effects

(b) No, it has no effects

[ ]

[ ]

7. Will these effects be in the short-or-long-run? Select one option:

(a) It will be in the short-run only

(b) It will be in the long -run only

(c) It will be in the short-and long-run

8. What in your option will be the short-run effects of land use charge? Select as many as applicable:

(a) Tax payable by property owner will increase

(b) Net rent will fall

(c) Both effects will be noticeable

9. What in your opinion will be the long -run effects of land use charge? Kindly rank the effects in order of importance. Please 1 for first choice, 2 for the next, etc by putting MARK against each option in Box below:

\begin{tabular}{|l|l|l|l|l|l|l|l|l|l|}
\hline S/N & Option & \multicolumn{5}{|l|}{ Rank (Please select ONE rank for each option) } \\
\hline & & 1 & 2 & 3 & 4 & 5 & 6 & 7 & 8 \\
\hline 1 & Tax burden will be passed on to the tenants & & & & & & & & \\
\hline 2 & Rents will increase & & & & & & & & \\
\hline 3 & More tenants to default in rent payment & & & & & & & & \\
\hline 4 & $\begin{array}{l}\text { In litigation arising from rent default and ejection of } \\
\text { tenants }\end{array}$ & & & & & & & \\
\hline 5 & Tenants will be worse off than before the imposition & & & & & & & & \\
\hline 6 & Housing developers will relocate to neighbouring States & & & & & & & & \\
\hline 7 & Land and property value will increase & & & & & & & & \\
\hline 8 & Stock of quality housing will decrease & & & & & & & & \\
\hline
\end{tabular}

10. The law provides that the land rate, neighbourhood improvement charge, and tenement rates would stop. Will you consider this an advantage or not? Please Select one option:
(a) It is an advantage
(b) It is a disadvantage

11. The law provides penalty for late settlement of rates as follows: charges will increase by $20 \%$ if payment is not made within 75 days; by $50 \%$ if not paid within 105 days; and by $100 \%$ if within 135 days; and the property become liable to receivership after 135 days. What is your opinion about this provision? Please Select one option:

(a) It is very harsh, the citizens do not deserve it

(b) It is alright, the citizens deserve it

(c) Others, please state your onion:

11. The law provides that anybody including the occupier of chargeable property may be declared to be the agent of the owner, and become liable for payment of the charge on behalf of the owner. Furthermore, the charge will become recoverable from the agent if owner defaults. What is your opinion about this? 
(a) This will be a great advantage

(b) This will be a great disadvantage

$\left[\begin{array}{ll}{[} & \\ {[} & ]\end{array}\right.$

12. What will you say are advantages of the law? Kindly rank the advantages. Please select 1 for first choice, 2 for the next, etc by putting MARK against option in the BOX below

\begin{tabular}{|l|l|l|l|l|l|}
\hline S/N & Option & \multicolumn{4}{l}{$\begin{array}{l}\text { Rank (please select ONE } \\
\text { rank for each option }\end{array}$} \\
\cline { 4 - 7 } & & 1 & 2 & 3 & 4 \\
\hline 1 & Consolidates the various taxes & & & & \\
\hline 2 & Increases internally generated revenues & & & & \\
\hline 3 & Reduces or prevent tax evasion & & & & \\
\hline 4 & Collection of charge easier through agents or occupier & & & & \\
\hline
\end{tabular}

13. What are the disadvantages? Kindly rank the disadvantages. Please select 1 for first choice, 2 for the next, etc by putting MARK against option in the BOX below:

\begin{tabular}{|c|c|c|c|c|c|c|c|}
\hline \multirow[t]{2}{*}{$\mathrm{S} / \mathrm{N}$} & \multirow[t]{2}{*}{ Option } & \multicolumn{6}{|c|}{$\begin{array}{l}\text { Rank (please select ONE rank for each } \\
\text { option) }\end{array}$} \\
\hline & & 1 & 2 & 3 & 4 & 5 & 6 \\
\hline 1 & Tax is rather too high because it is based on capita value & & & & & & \\
\hline 2 & It will discourage housing delivery & & & & & & \\
\hline 3 & Rent will increase & & & & & & \\
\hline 4 & $\begin{array}{l}\text { Basing tax on Capital Value means charging in perpetuity } \\
\text { but paid annually }\end{array}$ & & & & & & \\
\hline 5 & Does not consider the incidences of delayed rent payment & & & & & & \\
\hline 6 & $\begin{array}{l}\text { Imposition of penalty on delayed payment will cause } \\
\text { owners greater harm }\end{array}$ & & & & & & \\
\hline
\end{tabular}

14. What will you recommend? Select one option:
(a) That the law be repealed
(b) That the law be amended
(c) That the law be retained in its presents state
(d) Others, please state your opinion:

15. If you want the law to be repealed, in what ways? Select as many options as applicable
(a) The basis of valuation should be the net annual income and not capital value
[ ]
(b) Rent default rates of tenants in Lagos State should be considered and so considered [ ]
(c) Penalty for default payment should be once and not more than $10 \%$ per annum
(d) Provision for receivership should be removed from the law
(e) Others, please state :

Thank you

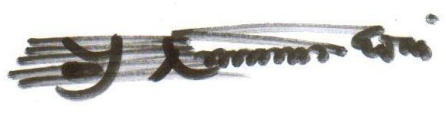

Dr Olawande Oni 